\title{
Translation as Stochastic Informational Process
}

\author{
Tamara A. Kazakova* \\ St. Petersburg State University \\ 7/9 Universitetskaya nab., St. Petersburg, 199034, Russia
}

Received 11.10.2015, received in revised form 09.02.2016, accepted 04.03.2016

The article touches upon the problem of regulating linguistic and extralinguistic information in translation that is considered as a stochastic process. Gains and losses on this way can be viewed based on such principles of regulating information as linear, combinatorial and probabilistic. The informational approach to translation allows investigating such phenomenon as residual entropy of the individual literary text and its role in choosing most appropriate if not accurate interlingual compatibles.

Keywords: information, translation, stochastic process, probabilistic regulation, residual entropy.

DOI: 10.17516/1997-1370-2016-9-3-536-542.

Research area: philology.

\section{Introduction}

It is acknowledged that translation is an informational process, in the course of which an amount of information is transferred to the target receiver by means of changing the code. Less acknowledged is relationship between information and code, i.e. whether information is relevant or irrelevant to the code if such code is a natural language. More often than not, we refer to language as a form opposed to meaning (or sense) as information. Meanwhile, information depends on form more than we prefer to assert. Unfortunately, when theories discuss informational approach to translation this interdependence is seldom considered, if at all. According to many translators of poetry, what we translate is sense, or meaning, and not form that is regarded as "decorative".
However, sense we, presumably, translate is not irrelevant to the code and their interrelationship may vary depending on the text, which makes us think of a different basis for a model of translation, e.g., the stochastic model that focuses at fuzzy equivalence. From this point of view, any seemingly untranslatable text may be transferred if we consider its form and meaning not as separate entities but in their interrelationship and its possible variants, thus as conveying a higher information load. Such a model is pertinent when we translate so called form-oriented texts (actually, authoring) and presume that form as such is untranslatable due to interlingual differences.

This interrelationship provides a far more amount of information to be perceived and transferred than meaning separated from the

(C) Siberian Federal University. All rights reserved

* Corresponding author E-mail address: tamakaza@gmail.com 
form. It is inevitably ambiguous and not directly available, thus, it needs some regulation in the process of perception and transfer. This article is meant to share some propositions on the probable ways of regulating this interrelationship as a fuzzy set of its properties, i.e., is an attempt to approach a stochastic model of translation. Stochastic models are probabilistic patterns in which a set of elements is interpreted as a distribution of probabilities. In respect of translation, stochastic approach deals with a probable set of verbal signs among which the translator chooses a one. The choice requires application of this or that regulation strategy that leads the translator through the set of signs. We will consider three possible principles of such a strategy - linear, combinatorial and probabilistic. Normally, the first two algorithms prevail and, sometimes, suffice, however, their potential is inconsistent when we deal with a more sophisticated choice.

\section{Linear regulation of informational data in translation process}

When we come to translate this or that verbal text we may perceive it as a set of verbal signs and each sign as a separate entity. On the lower level of processing information in translation suitable to represent what David Katan calls "the low information load" (Katan: 1999, 194), a separate verbal entity is the target. According to Katan, "one of the main aspects of low information load is the priority on simplicity" (Katan 1999, p. 195). Inexperienced translators apply this approach in the process of translation in an effort to avoid the problem of relativity and ambiguity. Both are the nightmare for the translator because they make him face the multiplicity of variants, that is, the high level of information load, and, consequently, force to choose among those variants. By ambiguity we mean, after C. Quiroga-Clare, ““”connotation, denotation and implication" and tropes as metaphor and allegory" (Quiroga-Clare: 2003,1), i.e. instruments of producing extra sense, thus providing hyperinformativity (Lotman: 1970, 90-91) of the verbal form. The strategy of avoiding any situation of choice involves the linear algorithm of processing information in translation; the utter example is word-for-word translation. Yet, typically, the linear strategy in translation is implemented in connecting a source sign with the most frequent variable of a sign in the target language, i.e., relying on frequency rather than on analysis. Actually, linear strategy is a deterministic variant of the stochastic process; the two differ from each other in the measure of determinacy.

Let us consider the example quite familiar to the translator community: the case of 'overt and covert translation', the term taken from the book of Julianne House where she argues her functionalpragmatic model for translation quality assessment and considers dimensional (pragmatic) and nondimensional (denotative) mismatches (House: 2015). The term 'overt' appears in the following context: "An overt translation is one which most overtly is a translation not, as it were, a 'second original' (House, 54). A covert translation is a translation which enjoys the status of an original source text in the target culture" (House, 56). These two terms have been widely used and interpreted in both English (Routledge: 2005, 199) and Russian (Sdobnikov: 2015, 37-38). The case manifests itself in the Russian translation of the two terms: they appear in different forms. For the dichotomy, V. Sdobnikov offers the Russian equivalent “явный" (overt) and “скрытый" (covert). However, as a non-widespread term in the Russian world of translation science, the word overt also appears in other variants: “открытый”, “очевидный”, “прямой”, sometimes even “регламентированный”. The situation becomes yet more complicated since in Russian translation 
models the term overt denotatively corresponds to the terms "буквальный" or "дословный" as opposed to "семантический, прагматический”. Thus, the one way of translating the English term is to use the linear strategy - with the result based on the evidence of the bilingual dictionary, i.e., on the finite number of matches. In this case, the process of translation becomes deterministic due to the use of countable entities: открытый, очевидный, явный, откровенный - other matches are not on the frequency scale. So the translator point is to choose one of four certain possibilities, in which case we can predict the result. The certainty of such decision will show the preferences based on the sequential net: the first entity in the line has all chances unless there are specified preferences. The only complication is conditioned by the brand of a bilingual dictionary; in some of them, the word "открытый” will open the line; others will use “явный” to open the line. Resulted are above-mentioned Russian matches. This strategy is acceptable for translation of special, scientific texts in accordance with the requirements of exact, or dictionary-based equivalent terms and transfers the original term on the basis of simplicity and clarity of the choice. It does not necessarily refer to an inexperienced translator (or any other kind of mediator) and may be used in the situation of the necessity of a quick decision (e.g., in interpreting) or a special task (e.g., in the so-called exact translation or terminology translation). The simplicity and clarity involved, linear decisions are based on a clear-cut model of direct or even formal correspondence in translation without taking into consideration such informational constituents as expression, rich style, or associative potential that require a different kind of translation strategy. Actually, this principle of processing information in translation is sufficient on the level of separate verbal units - and in the texts whose informational load is low.

\section{Combinatorial regulation of the translation process}

The linear strategy is convenient and, in many cases, quite reliable. However, there are situations when the boundaries of equivalence in translation this or that text are not powerfully determined and what is required is to transfer not only the denotative meaning of a word but the measure of emphasis in a certain context. Thus contextual factor is involved into the process of translation enhancing the number of possible variables of equivalence, and then more productive answer to this challenge is the combinatorial strategy that takes into account not only separate items but the number of their possible combinations with other items, i.e., micro-contexts. This translation strategy is more reliable to focus on transferring a higher information load. Close to this issue is the "idiomatic approach" in translation studies (Riabceva: 2013, 89 - 93). By idiomaticity we do not only mean set expressions but a wider approach to different types of combinative patterns regulated by this or that language system in different ways. When we transfer the original information marked by the idiomaticity we do not take into account separate words but their combinations allowed by SL in comparison with those allowed by TL. This will lead the translation search beyond linear probability that minimises randomness of the translator choice and will require a progressive inventory of possible matches, which, in its turn, enhances the stochastic distribution of comparing properties of linguistic signs.

The random distribution of informational properties predetermines the translation search beyond the denotative meaning of separate words into such factors as standard use and stereotype assessment of their combinations. The English word "heavy" in linear transfer corresponds to the natural Russian match “тяжелый", which implies such connotations as "weight", 
“burden", "load" (“тяжесть, груз, вес", еtc.), and their connotative properties as of separate signs more or less coincide implying negative associations. However, their combinatorial distribution differs between English and Russian and the number of mismatches, i.e., the discrepancy rate, is high and shows a different set of associations. This discrepancy is partly regulated by the dictionary but some contexts need logical or heuristic decisions, including those not proposed by the dictionary. For example, if "heavy load" finds a linear match in Russian as “тяжелый груз” and, thus, shows compatibility as the image of material weight, then such combination as "heavy burden" corresponds to the Russian“"тяжкое бремя" and involves moral rather than material, though negative appraisal. Yet greater difference is between the English "heavy applause" and the Russian "бурные (продолжительные) аплодисменты = овация": in this case, the implication is intensity, definitely positive in Russian, while the choice is discrete.

Based on polysemic status of the word, the example indicates the mounting stochastic discrepancy that grows with the increasing number of probable patterns of combinations. With all this, the discrepancy reflects standard use of the combinations, and, differentiated as they are, the translator search is implemented within certain boundaries that presuppose steady interlingual idiomatic correspondences, whatever multiple. More unpredictable complications occur when the translator deals with non-standard use of linguistic signs if the author of ST sets out his own patterns of expression yet enhanced by the interlingual asymmetry. In such situations, the high information load under the intricate stylistic means, which is usually qualified as the rich style, requires the application of the probabilistic translation strategy.

\section{Probabilistic regulation of information in translation}

Non-standard use of linguistic signs and patterns is interrelated with growing amount of information enhanced by complicated, sometimes unique patterns that the author constructs for the occasion. Qualified by V.V. Ivanov as residual entropy (Ivanov: 2004, 150), which, in its turn, is regarded as a constituent of the informational flexibility of the text (Kolmogorov: 1987, 214), this phenomenon reflects the capacity of the literary text to convey, apart from ideas, also emotional, axiological, aesthetical and other components of information. These components manifest themselves, with special forms of the text that regulate combinatorial patterns of verbal signs and, at the same time, release their potential powers to convey unconventional information. Such forms are different means of expression that are associated with the idea of the rich style in fiction of individual literary texts and/or specific informational media like rhyme, rhythm, reiterations, and/or alliteration in poetic texts.

Thus, enhancing entropy of the unconventional use of verbal signs in some categories of text, individual by their nature, presupposes a certain level of complexity that requires various probabilistic strategies to be applied by the translator. E.g. the rhymed word is not informatively equal to the same word used separately: under the rhyme, two words form a particular verbal sign, a couple interrelated not only phonetically but also semantically, and the more unusual the rhymed relationship, the greater information depth of the couple. The very phenomenon of the accumulation of informational complexity and depth of the text regulated with such media is not available to direct perception: you need more sophisticated tools of analysis and text processing to comprehend and transfer these properties of the original retaining the covert components 
of information. Most powerful tools in search of the information depth are probabilistic. The translator does not rely on the surface semantics of the rhymed words but concedes that there is some specific information in the very fact of rhyming them; and if he omits the rhyme, he loses that information in translation. This does not mean that the rhyme itself as a form of combination matters but its supposed meaning. In other words, you ask yourself: what is the use of the rhyme? There are a number of possible answers - the rhyme is for the sake of decoration; for the sake of itself as a mark of poetic diction; as a mnemonic device; as a means of melodic pattern; etc. Let us add some more possibilities: the rhymed words convey some deeper information that can be logically revealed and, thus, perceived as an implicit complicated image unexpressed directly in a separate verbal sign. Let us work on the example of English translations of a poem by Osip Mandelstam.

Мы живем, под собою не чуя страны.

Наши речи за десять шагов не слышны.

(Mandelstam: 1990, 196)

This is a famous poem from the collection Moscow Notes (1933); it has been repeatedly translated into English, and, mostly, without any such "trifles" as rhyme. What has become with the rhymed pair “страны - не слышны” and if the losses are so significant? Mandelstam's rhyme conveys both expressive (the echoing vowels) and emotive (moaning sounds); besides, the choice of rhyming words themselves activates their semantic interrelationship indicating the connection with the cultural (historical, social, ideological) environment, thus constructing the two oppositions of significance for the whole text: “мы :: страны” and “наши речи :: не слышны”. This enclosed construction involves, apart from dictionary semantics, cultural associations into the perception of the text, i.e., collective via individual experience: you live in the country but you are isolated, you utter words but they are quenched. Yet, we live and we utter words, and the words become unquenchable.

Considering this brief reconstruction, we fail to find most of those informational components in the translated texts due to the less regulated way of expression. More than that, the translators use mismatches such as earth and ground for "страна", which distorts the cultural components mentioned above and, actually, asserts the axiological and emotional shift in the perception: we live but have lost the ground (do not understand things, are lost, discouraged, etc.); our words sound in vain and evaporate. This interpretation offers an opposite vision in comparison with Mandelstam's original: despair and lament instead of courage and fortitude. Supposedly, the more appropriate decision would be, at least, closer semantic correspondence "country", while "evaporate" does not fit the set of contexts reconstructed above.

\section{We live, not feeling the earth beneath us \\ At ten paces our words evaporate. \\ (Stalin Epigram by Osip Mandelstam / translation by Darran Anderson)}

Our lives no longer feel ground under them.

At ten paces you can't hear our words.

(Translated by W.S. Merwin and Clarence Brown)

These variants show how easily translators can lose the original information by a number of seemingly slight shifts. By means of the probabilistic approach that offer such tools as informational flexibility and residual entropy as regards to individual literary texts, the translator can optimize processing such texts in translation. In particular, one can concede the multiplicity 
of possible interpretations of the text and choose within a fuzzy set of matches.

\section{Conclusion}

The brief account of such possible approaches to information transfer as linear, combinatorial and probabilistic show that translation as stochastic informational process passes on different levels of the translator search. The level of considering verbal signs as separate entities narrows the field of choices; resulting from this strategy is the exact but not necessarily accurate regulation of the original information. In this case, only separate units and bits of the original information are perceived and reconstructed in the target text. More productive is the combinatorial regulation that takes into account groups of verbal signs (lingual micro-contexts) and thus allows a wider range of the information search resulting in closer semantic matches. The probabilistic level of processing the original information in translation opens a wide field of possible key points that can be regulated with the help of such tools as residual entropy and informational flexibility of an individual literary text in which the use of verbal signs is unconventional and interrelated with extralinguisitc reality.

\section{References}

Against Forgetting (1989). Ed. by Carolyn Forché. W.W. Norton \& Co., p. 123.

Ivanov, V.V. (2004). Lingvisitika tretjego tysiacheletia [Linguistics of the Third Millenium]. Moscow, Yazyki slavianskoi kultury, 2004. 208 p.

Katan, D. (1999).Translating Cultures: An Introduction for Translators, Interpreters and Mediators. St. Jerome Publishing, $270 \mathrm{p}$.

Kolmogorov, A.N. (1987). Teoriya informacii I teoriya algoritmov [A Theory of Information and a Theory of Algorithms]. Moscow, $223 \mathrm{P}$.

Lotman, Y.M. (1970). Struktura khudozhestvennogo teksta [The structure of the poetic text]. Moscow, Iskusstvo, $384 \mathrm{p}$.

Mandelstam, O. (1990). Stikhotvoreniya. Ocherki. Perevody. Statyi [Poems. Essays. Translations. Articles.]. Tbilisi, Merani, 415 p.

Riabceva, N.K. (2013). Prikladniye problemy perevodovedeniya: Lingvistichesky aspect [The Applied Problems of Translation Studies: Linguistic Aspect]. M.: FLINTA-Nauka, 224 p.

Routledge Encyclopedia of Translation Studies (2005). L.-N.Y, 654 p.

Sdobnikov, V.V. (2015). Otsenka kachestva perevoda. Kommunikativno-funktsionalny podkhod [Translation Quality Assessment. Communicative-Functional Approach]. M.: FLINTA-Nauka, 108 p.

House, J. (2015(1998).Translation Quality Assessment: Past and Present. Routledge, 160 p.

Quiroga-Clare C., Language Ambiguity: A Curse and a Blessing. In Translation Journal, 7(1). Available: http://translationjournal.net/journal/23ambiguity.htm (Accessed: 2 Feb 2016).

Stalin Epigram by Osip Mandelstam. Transl. by Darran Anderson. In Cipher Journal. Available: [http://www.cipherjournal.com/html/mandelstam.html] (accessed 5 Feb 2016). 


\section{Перевод как стохастический \\ информационный процесс}

Т.А. Казакова

Санкт-Петербургский государственный университет

Россия, 199034, Санкт-Петербург,

Университетская набережная, 7-9

Статья посвящена проблеме упорядочивания лингвистической и экстралингвистической информации при переводе, который рассматривается как стохастический процесс. Успехи и потери в этом процессе можно представить на основании таких принципов упорядочивания информации, как линейный, комбинаторный и вероятностный. Информачионный подход $\kappa$ переводу позволяет исследовать такой феномен, как остаточная энтропия авторского художественного текста и ее роль в выборе оптимальных, хотя не единственно правильных межъязыковых соответствий.

Ключевые слова: информация, перевод, стохастический процесс, вероятностное упорядочивание, остаточная энтропия.

Научная специальность: 10.00.00 - филологические науки. 